\title{
高温焼成カオリンの固体酸性とプロピレン オキシドの異性化反応
}

\author{
阿部 将起 ${ }^{\dagger}$, 菖蒲 明己* \\ 室蘭工業大学工業化学科, 050 室蘭市水元町 27-1 \\ †現在 : チッソ石油化学(株), 290 市原市五井海岸
}

(昭和 60 年 9 月 5 日受理)

\begin{abstract}
高温焼成酸化物（七ラミックス）の表面性質を調べる目的で，天然粘土鉱物カオリンを大気中，2時間，700〜 $1,500^{\circ} \mathrm{C}$ で焼成した試料の固体酸塩基性を IR 法と滴定法によって，プロピレンオキシド開環異性化反応に 対する 活性, 選択性を反応温度 $300^{\circ} \mathrm{C}$, パルス反応法で調べた。酸密度は焼成温度 $1,000^{\circ} \mathrm{C}$ 以下の試料（メタカオリンと $\mathrm{Al}-\mathrm{Si}$ スピネル構造) と比べ, $1,100^{\circ} \mathrm{C}$ 以上の試料（ムライト構造の生成領域）では半減したが，プロピレンオキシ ド異性化の比速度は逆に倍増した。主生成物質は $\mathrm{L}$ 酸点上で起こるプロピオンアルデヒドと L 酸点と塩基点の共役で 生成するアリルアルコールであった。後者の生成とジクロロ酢酸の毒効果は塩基点の存在を示唆した。
\end{abstract}

\section{1. 緒}

固体酸性酸化物を高温焼成すると酸量は減少し，酸強度は弱 くなることは明らかである。しかし反応によっては最適な酸強 度を必要とし，時にはこれの均一化を不可欠とする場合も考え られる。また反応物質の分子サイズあるいは骨格構造と活性点 間距離との整合性も固体触媒の機能性を高める上で検討されな ければならない課題の一つと考えられる。もちろん, 細孔構造 の特性化も考慮の対象之なるのであろら。

一方，高温焼成の 金属酸化物は狭義の七ラミックスと呼ば れ，触媒分野では触媒活性を有しないと考えられている。その ため触媒担体として, 不活性な反応管充てん風（例兄ば熱伝導 体）として使用されているのが一般的である。しかし，固相变 化を伴う物質の場合は，この相転移過程における表面組織の变 化を適当な方法で中断させることによってその固体表面の酸塩 基性に特長をもたせることも可能である。近年，高価な金属す なわち貴金属を用いた触媒調製が盛んに研究されているが, 一 方で安価な物質を用いて表面性質の特性化をはかることによっ て新機能触媒を調製する努力も必要と考えられる。特に貴金属 の資源をもたない国にとっては重要な研究課題となり得る。

本研究はこのよらな観点から, 天然の粘土鉱物であるカオリ ソの高温焼成による表面酸性質の変化を調べ，カオリン特有の

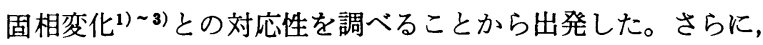
高温焼成試料表面の触媒機能を調べる目的で，比較的良く研究 され，基本的な反応機構が知られているプロピレンオキシドの 開環異性化反応(4) 9)をモデル反応として採用した。この物質は ブレンステット酸, 強い塩基点上ではオリゴマー, あるいは重 合物質を形成することも知られている。10),11)さらに，骨格異性 化反応によってアリルアルコール, アクロレイン等が生成し, これらが生成するには塩基点の関与を必要とすることも知られ ている。6) -9) したぶって，この異性化反応の生成物を調べるこ とによって塩基点の存在について知見を得ることが可能であ

*連絡先
る。

\section{2. 実験}

流通反応器では反応初期のいわゆる清浄表面に対応する反応 挙動に関する情報が得られ難い。この理由からガスクロマトグ ラフを用いるパルス反応法を採用した。プロピレンオキシド (PO と略記) の開環異性化反応はガラス管壁でも起こるの で，反応管には $560^{\circ} \mathrm{C}, 2 \mathrm{~h}$ ，大気中で焼鈍した内径 $2 \mathrm{~mm}$ の Pyrex ガラス管を, 触媒床にはアセトン洗浄ガラスウールを使 用した。ブランク反応テストでは反応温度 $450^{\circ} \mathrm{C}$ で PO 全反 応率は $1 \%$ 以下であった。なお，各反応ごとに 新しい反応管 を使用した。

PO は市販試薬 (東京化成 (株), 純度 $99 \%$ 以上)を 3 回真 空蒸留したもので，これを $4 \mathrm{vol} \%$ に $\mathrm{He}$ で希釈してフラス コに蓄留した。パルスは $1.88 \mathrm{ml}$ のループ付 5 方ガラスコッ クを用いて送入し，パルスサイズ $4 \times 10^{-7} \mathrm{~mol} \mathrm{(stp)，パルス}$ 間隔約 40 分であった。ガス分析には DEGS $15 \mathrm{wt} \% / \mathrm{C}-22$ 充てんカラム $\left(4 \mathrm{~mm} \phi \times 6 \mathrm{~m}, 85^{\circ} \mathrm{C}\right)$ を用い, キャリヤーには 市販の $\mathrm{He}$ （純度 $99.99 \%$ ）をそのまま用い，流速は $13.3 \mathrm{ml}$. $\min ^{-1}(\mathrm{stp})$ 一定とした。生成物の同定はクロマトグラムの保 持時間と IR 吸収スペクトルによって確認した。

比表面積は蒸留 $\mathrm{N}_{2}$ を用いた BET 法で測定し, 吸着ピリシ ン $(\mathrm{Py})$, 吸着 $\mathrm{CO}_{2}$ の IR 吸収スペクトルは日立赤外分光光 度計 215 型を用い, 室温, in situ で測定した。また，カオリ ンの組成分析は蛍光X線分析装置（理学電機 No. 9578）を用 い,ビードサンプル法, 粉末法を併用して定量した。

酸量の測定は $0.01 \mathrm{~N}$ のハメット指示薬, $0.01 \mathrm{~N} n$-ブチル アミン溶液を用いた滴定法で行い, 塩基量測定には同濃度の安 息香酸溶液を用いた。ベンゼンは市販特級試薬（関東化学）で 開封後 2 日以内でのみ使用した。

触媒として用いたカオリンはキシダ化学の China Clay (300 メッシュ) である。この約 $1 \mathrm{~g}$ を高純度アルミナセラミック SSA-S（日本陶業(株)）のボートおよび同セラミック管を炬し 
几管とするシリコニット電気炉を用いて大気中， 2 時間焼成し た。焼成後の試料の取扱いは可能な限り乾燥窒素ガスをパージ したグローブボックス中で行い，反応に使用するまで窒素ガス 中に保管した。

\section{3. 実験結果と考察}

\section{1 バルク組成}

$500^{\circ} \mathrm{C}$ 焼成カオリンの蛍光 $\mathrm{X}$ 線分析による組成は酸化物と して $\mathrm{SiO}_{2} 71.1, \mathrm{Al}_{2} \mathrm{O}_{3} 27.4, \mathrm{~K}_{2} \mathrm{O}$ 0.9, $\mathrm{Na}_{2} \mathrm{O}$ 0.3, $\mathrm{Fe}_{2} \mathrm{O}_{3}$ 0.07, $\mathrm{TiO}_{2} 0.19 \mathrm{wt} \%$ であった。 $\mathrm{MgO}, \mathrm{CaO}, \mathrm{Cu}_{2} \mathrm{O}, \mathrm{ZnO}$ および $\mathrm{S}$ は $0.001 \mathrm{wt} \%$ 以下であった。 $\mathrm{K}_{2} \mathrm{O}$ 以下の不純物は 高温の焼成で表面層に濃縮すると考えられるが，本実験は大気 中焼成であるので安定な酸化物形態で存在するであろう。塩基 性物質は PO の重合反応活性をもつが，開環異性化反応に は不活性であった。 $\mathrm{TiO}_{2}$ は $\mathrm{Al}_{2} \mathrm{O}_{3}, \mathrm{SiO}_{2}$ と同程度の活性をも つ12)が, 以下の理由で $\mathrm{TiO}_{2}$ の影響は無視できる。もし, 高温 の焼成ほど $\mathrm{TiO}_{2}$ の表面濃縮が著しく起こり，これがL酸点発 現の主要因であるならば $n$-ブチルアミン吸着量は焼成温度の 高いほど増大し，PO 異性化反応の比速度も増大することにな る。本実験の結果では前者の傾向は全く観測されていない(3.3 参照)。また, $900 〜 1,500^{\circ} \mathrm{C}$ で焼成した純 $\mathrm{TiO}_{2}$ 上では $\mathrm{PO}$ 異性化反応の比速度は高温焼成試料ほど増大した。 ${ }^{12)}$ しかし, カオリン焼成試料では $1,100^{\circ} \mathrm{C}$ で最大值を与えるが，より高 温側では逆に減少している (Fig. 4 参照)。

$\mathrm{Fe}_{2} \mathrm{O}_{3}$ については, $\gamma$ 相であればスピネル構造で空格子点を もつが, $600^{\circ} \mathrm{C}$ 以上では $\alpha$ 相となるため, 表面濃縮が起きても PO に対し Table 3 のような活性をるつことはないと考える。

\section{2 比表面積変化と構造}

カオリンの焼成にともなら比表面積の変化を Table 1 に示 した。700, 900 1,000, および $1,300^{\circ} \mathrm{C}$ で急速に比表面積が 減少し, 固相反応の起きていることがわかる。

カオリンは加熱により 4 種類の構造変化を起こすことが知ら れており，水またはクリスバライト $\left(\mathrm{SiO}_{2}\right)$ の遊離による高了 ルミナ複合酸化物すなわちムライトに段階的に变化する。卓 3)

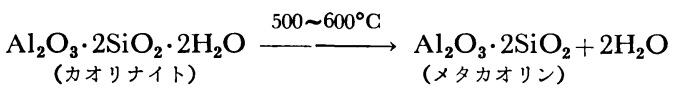

$$
2\left(\mathrm{Al}_{2} \mathrm{O}_{3} \cdot 2 \mathrm{SiO}_{2}\right) \stackrel{\sim}{\stackrel{980^{\circ} \mathrm{C}}{\longrightarrow}} \underset{(\mathrm{Al}-\mathrm{Si} \text { スピネル) }}{2 \mathrm{Al}_{2} \mathrm{O}_{3} \cdot 3 \mathrm{SiO}_{2}}+\mathrm{SiO}_{2}
$$

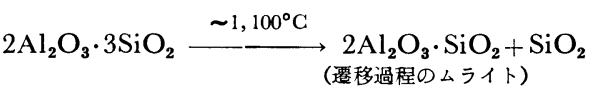

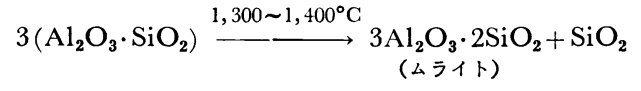

メタカオリンでは $\mathrm{Al}^{3+}$ は 4 配位（カオリナイトでは 6 配 位）で二次元的配列も保っている。約 $980^{\circ} \mathrm{C}$ で起こる $\mathrm{Al}-\mathrm{Si}$ スピネル構造は結晶度の悪い等軸晶系の結晶相で 4 配位 $\mathrm{Al}^{3+}$ が種々の割合で $\mathrm{Si}^{4+}$ によって置換された構造になっている。 さらに加熱するとクリストバライトの遊離が進行し, $\mathrm{Al}_{2} \mathrm{O}_{3} /$ $\mathrm{SiO}_{2}=1 / 1$ の遷移過程のムライト構造をとる。結晶相のしっか りしたムライト構造は $1,100^{\circ} \mathrm{C}$ 付近からも生成するが 1,300 ${ }^{\circ} \mathbf{C}$ 以上で急速に成長し熱的には極めて安定といわれている。 本研究のように高温領域の焼成においても Eqs. (2)〜 (4) のよ らにバルク構造からのクリストバライトの拔け出しによって生 ずる空格子点の存在が考えられ，適当な反応系に対し活性を有 することが予測される。Table 1 の比表面積の変化は上記の 結晶構造の変化と良く対応し，遊離したクリストバライトの PO に対する異性化活性は無視できる。

\section{3 酸量, 塩基量の変化}

所定温度で焼成した試料を再び真空系内， $450^{\circ} \mathrm{C} ， 1$ 時間 排 気脱水したのち, 試料管を乾燥空気で満たし, すばやく $10 \mathrm{ml}$ のベンゼンを投入し，共栓付三角フラスコに移した。これに八 メット指示薬 3 滴を加光, 2 3 時間かけて $n$-ブチルアミンを 滴下した。測定された酸量を Table 1 に示してある。500, $700^{\circ} \mathrm{C}$ 焼成試料の $\mathrm{H}_{0} \leqq+3.3$ の酸量は $0.022 \mathrm{mmol} \cdot \mathrm{g}^{-1}$ で Benesi の報告值 ${ }^{13}$ ) $0.02 \mathrm{mmol} \cdot \mathrm{g}^{-1}$ (米国サウスカロライナ産 カオリン）と同程度である。 $\mathrm{H}_{0} \leqq+3.3, \mathrm{H}_{0} \leqq+4.8$ の両酸量 は焼成温度とともに減少している。後述するように $1,500{ }^{\circ} \mathrm{C}$ 焼成試料も活性を有するので $\mathrm{H}_{0} \leqq+4.8$ の単位表面積当たり の酸量 (酸密度 $\mathrm{mmol} \cdot \mathrm{m}^{-2}$ ) を求めると, メタカオリン, $\mathrm{Al}-\mathrm{Si}$ スピネル構造をとる焼成物表面とムライト系の構造をもつ表面 の酸密度に差異がみられ，その比は 2.6 対 1 であった (Table 1)。これは明らかに比表面積変化より小さく, 高温の焼成過程 で新たに酸点が発現していることを示唆する。

\begin{tabular}{|c|c|c|c|c|c|c|}
\hline \multirow{2}{*}{$\begin{array}{l}\text { Calc. } \\
\text { Temp. } \\
\left({ }^{\circ} \mathrm{C}\right)\end{array}$} & \multirow{2}{*}{$\begin{array}{l}\text { Surface } \\
\text { Area } \\
\left(\mathrm{m}^{2} \cdot \mathrm{g}^{-1}\right)\end{array}$} & \multicolumn{2}{|c|}{ Acidity } & \multirow{2}{*}{$\begin{array}{l}\text { Basicity } \\
\mathrm{H}_{0} \geqq+7.2 \\
\left(\mathrm{mmol} \cdot \mathrm{g}^{-1}\right)\end{array}$} & \multirow{2}{*}{$\begin{array}{c}\text { Acid Density } \\
\mathrm{H}_{0} \leqq+4.8 \\
\left(\mathrm{mmol} \cdot \mathrm{m}^{-2} \times 10^{2}\right)\end{array}$} & \multirow{2}{*}{$\begin{array}{l}\text { Site-site } \\
\text { Length } \\
\quad(\mathrm{nm})\end{array}$} \\
\hline & & $\begin{array}{c}\mathrm{H}_{0} \leqq+4.8 \\
\left(\mathrm{mmol} \cdot \mathrm{g}^{-1}\right)\end{array}$ & $\begin{array}{c}\mathrm{H}_{0} \leqq+3.3 \\
\left(\mathrm{mmol} \cdot \mathrm{g}^{-1}\right)\end{array}$ & & & \\
\hline $\begin{array}{l}500 \\
700 \\
900\end{array}$ & $\begin{array}{l}7.50 \\
7.24 \\
5.05\end{array}$ & $\begin{array}{l}0.205 \\
0.190 \\
0.132\end{array}$ & $\begin{array}{l}0.020 \\
0.013 \\
0.007\end{array}$ & $\begin{array}{l}0 \\
0 \\
0\end{array}$ & $\begin{array}{l}2.73 \\
2.63 \\
2.61\end{array}$ & $\begin{array}{l}0.27 \\
0.28 \\
0.28\end{array}$ \\
\hline $\begin{array}{l}1,000 \\
1,100 \\
1,300 \\
1,500\end{array}$ & $\begin{array}{l}4.67 \\
2.81 \\
1.25 \\
0.49\end{array}$ & $\begin{array}{l}0.113 \\
0.029 \\
0.011 \\
0.0037\end{array}$ & $\begin{array}{l}0.005 \\
0.003 \\
0.002 \\
0.000\end{array}$ & $\begin{array}{l}0 \\
0 \\
0 \\
0\end{array}$ & $\begin{array}{l}2.42 \\
1.03 \\
0.88 \\
0.74\end{array}$ & $\begin{array}{l}0.29 \\
0.44 \\
0.48 \\
0.52\end{array}$ \\
\hline
\end{tabular}

Table 1 Physicochemical Properties of Kaolin Samples Calcined at Various Temperatures for $2 \mathrm{~h}$ in Air

Estimated from moles of $n$-Butylamine adsorbed.

\footnotetext{
$\dagger 1,000,1,050^{\circ} \mathrm{C}$ 焼成シリカゲル上では Table 2 と同じ反応条件で全転換率はそれぞれ $6.2,0.2 \%, n_{\mathrm{AA}} / n_{\mathrm{PA}}$ は $0.1,0.0$ で あった。
} 


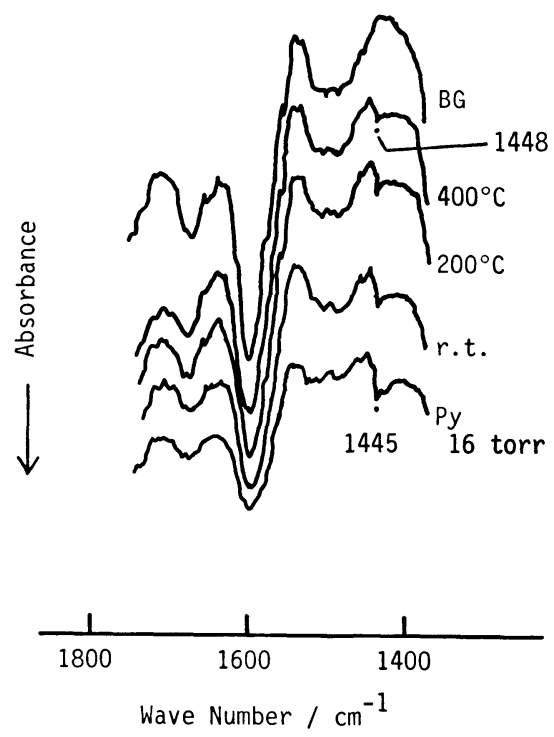

Fig. 1 Infrared Spectra of Pyridine Adsorbed on Kaolin Calcined at $500^{\circ} \mathrm{C}$ for $2 \mathrm{~h}$ in $\operatorname{Air}$ (r.t., 200, and $400^{\circ} \mathrm{C}$ show evacuation temperatures, and BG implies background)

一方, $\mathrm{H}_{0} \geqq+7.2$ の指示薬ブロモチモールブルーを用いて塩 基量の測定を試みたが十分な発色を示さなかった。

\section{4 ピリジン吸着}

大気中, $500^{\circ} \mathrm{C}, 2$ 時間焼成したディスクを IR in situ セル に移し， $400^{\circ} \mathrm{C}, 1$ 時間排気した。これに室温で Py 16 Torr を導入し 30 分吸着させたのち, 室温 15 分, 他の排気温度で は 30 分, 10-4 Torr 水準で排気し, 吸着 Py の IR 吸収ス ペクトルを測定した（Fig. 1)。カオリンの構造による吸収が $1,470 \sim 1,650 \mathrm{~cm}^{-1}$ の領域にあるので十分な強度をもつスペク トルは得られ難いが， $1,445 \sim 1,448 \mathrm{~cm}^{-1}$ にL酸点上の吸着 Py に帰属されるピークは $400^{\circ} \mathrm{C}$ 排気後も確認できた。また $1,000^{\circ} \mathrm{C}$ 焼成ディスク上でも微弱であるが $1,445 \mathrm{~cm}^{-1}$ の吸収 ピークを確認している。

塩基点上への $\mathrm{CO}_{2}$ 吸着を試みたが該当する IR 吸収ピーク は得られなかった。しかし，この結果は塩基点の存在をすべて 否定するものではない。

\section{5 プロピレンオキシドの異性化反応}

所定温度で焼成した試料 $8.3 \mathrm{mg}$ を反応管に充てんしたの

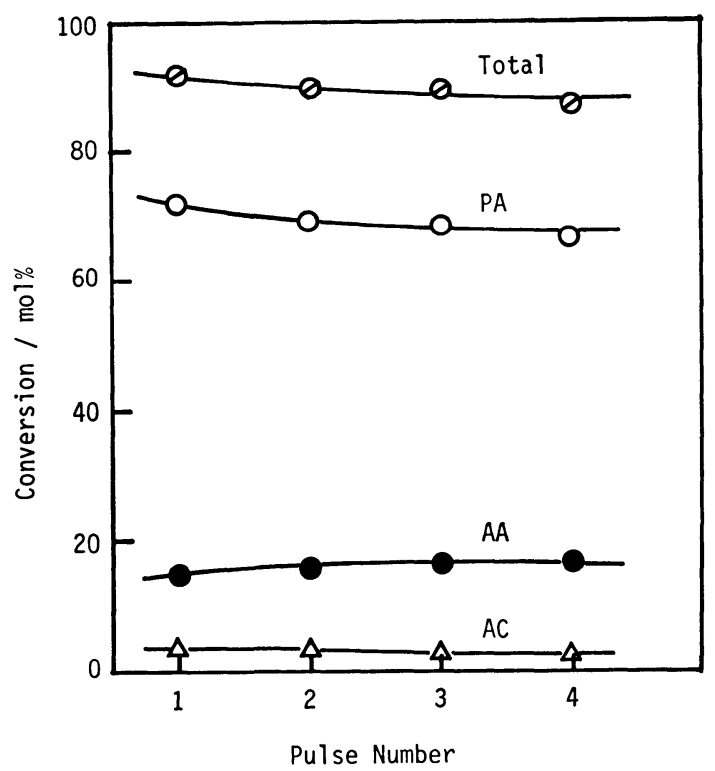

PA : propionaldehyde, AA : allyl alcohol $\mathrm{AC}$ : acetone

Fig. 2 Variation in Conversion to Main Products with Pulse Number over Kaolin Calcined at 1,100 ${ }^{\circ} \mathrm{C}$ for $2 \mathrm{~h}$ in Air (reaction temperature $300^{\circ} \mathrm{C}$, catalyst weight $8.3 \mathrm{mg}$, pulse size $4.0 \times 10^{-7} \mathrm{~mol}$ of propylene oxide)

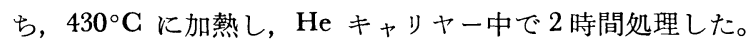

異性化生成物はプロピオンアルデヒド (PA), アリルアルコ ール (AA), アセトン (AC), アクロレイン (ACR), 1-プロ パノール $(\mathrm{PrOH})$ であった。反応のマスバランスの検討結果, 触媒上への沈着物の生成が認められたが $900^{\circ} \mathrm{C}$ 焼成試料上で $2.4 \%$, 他は $1 \%$ 以下であった。

Fig. 2 は $1,100^{\circ} \mathrm{C}$ 焼成試料, 反応温度 $300^{\circ} \mathrm{C}$ で得られた 反応の経時变化を示している。 $\mathrm{ACR}, \mathrm{PrOH}$ への転換率は $1 \%$ 以下で経時変化もなかったので示していない。清浄表面の触媒 性能を評価するには初回パルスの結果が最適であるが, Fig. 2 のよらに転換率の変動が小さいのでデータの信頼性を高める目 的で第 1 3 パルスの平均值で反応結果を整理した。

種々の焼成カオリン試料上で得た反応結果を Table 2 にま とめた。 AC, ACR および $\mathrm{PrOH} へ の$ 転換率は全体に小さ

Table 2 Conversion Data on Propylene Oxide over Kaolin Samples Calcined at Various Temperatures for $2 \mathrm{~h}$ in Air *a)

\begin{tabular}{|c|c|c|c|c|c|c|c|}
\hline \multirow{2}{*}{$\begin{array}{l}\text { Cal. } \\
\text { Temp. }\left({ }^{\circ} \mathrm{C}\right)\end{array}$} & \multicolumn{6}{|c|}{ Conversions $\quad(\mathrm{mol} \%)$} & \multirow{2}{*}{$\frac{\left.n_{\mathrm{AA}} * \mathrm{c}\right)}{n_{\mathrm{PA}}}$} \\
\hline & PA & AA & $\mathrm{AC}$ & ACR & $\mathrm{PrOH}$ & PLM *b) & \\
\hline $\begin{array}{l}500 \\
700 \\
900\end{array}$ & $\begin{array}{l}71.3 \\
67.4 \\
47.2\end{array}$ & $\begin{array}{l}13.6 \\
15.8 \\
15.5\end{array}$ & $\begin{array}{l}4.2 \\
2.8 \\
1.6\end{array}$ & $\begin{array}{l}1.8 \\
1.3 \\
0.6\end{array}$ & $\begin{array}{l}1.8 \\
0.9 \\
0.5\end{array}$ & $\begin{array}{l}0.0 \\
0.2 \\
2.4\end{array}$ & $\begin{array}{l}0.191 \\
0.234 \\
0.328\end{array}$ \\
\hline $\begin{array}{l}1,000 \\
1,100 \\
1,300 \\
1,500\end{array}$ & $\begin{array}{r}46.8 \\
70.1 \\
27.9 \\
8.4\end{array}$ & $\begin{array}{r}14.8 \\
15.4 \\
6.0 \\
1.6\end{array}$ & $\begin{array}{l}1.6 \\
2.6 \\
1.0 \\
0.5\end{array}$ & $\begin{array}{l}0.6 \\
1.0 \\
0.0 \\
0.0\end{array}$ & $\begin{array}{l}0.2 \\
0.9 \\
0.0 \\
0.0\end{array}$ & $\begin{array}{l}0.7 \\
0.0 \\
0.0 \\
0.0\end{array}$ & $\begin{array}{l}0.316 \\
0.220 \\
0.215 \\
0.190\end{array}$ \\
\hline
\end{tabular}

*a) Reaction conditions : cat. $8.3 \mathrm{mg}$, temp. $300^{\circ} \mathrm{C}$, pulse size $4 \times 10^{-7} \mathrm{~mole}$.

*b) PLM implies polymer-like materials.

*c) Mole ratio of $\mathrm{AA}$ to $\mathrm{PA}$ produced. 


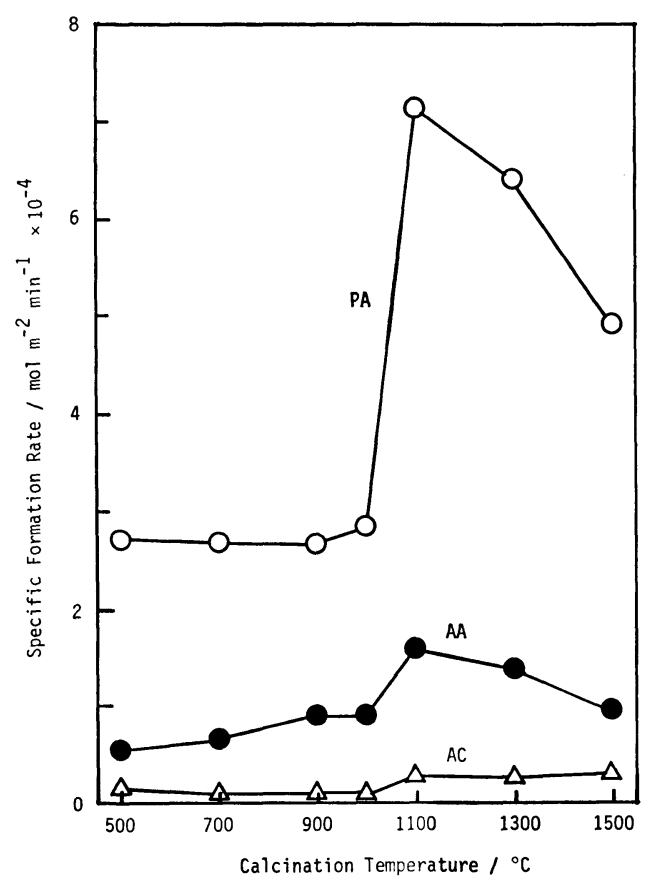

Fig. 3 Dependence of the Specific Formation Rates of Main Products on Calcination Temperature (reaction temperature $300^{\circ} \mathrm{C}$ )

く，かつ高温度焼成ほど一様に低下した。PA も同様の傾向を もつが， $1,100^{\circ} \mathrm{C}$ 焼成では $500^{\circ} \mathrm{C}$ と同程度生成した。一方 AA の生成は $1,100^{\circ} \mathrm{C}$ まで注定でより高温域では急激に 低下した。

焼成温度によって比表面積は著しく变化する。各異性化物の 比生成速度と焼成温度の関係は非常に 興味ある結果を与えた (Fig. 3)。すべての比生成速度は $1,100^{\circ} \mathrm{C}$ で極大を示し， $\mathrm{AC}$ 以外はより高温域で再び減少した。PA の比生成速度が 1,000 ${ }^{\circ} \mathrm{C}$ まで変化しない事実は $\mathrm{PA}$ 生成に関与する活性点密度に変 動のないことを示唆する。一方カオリナイトからメタカオリン を生成する場合の脱水反応が $500 \sim 600^{\circ} \mathrm{C}$ で全て完了すること は考光難い。AA の比生成速度の $1,000^{\circ} \mathrm{C}$ までの漸增は緩慢 に起こる脱水過程とメタカオリンおよび $\mathrm{Al}-\mathrm{Si}$ スピネル構造 への固相変化の過程で発現する活性点の増加によるものと考光 られる。

すべての 比速度が極大となる $1,100^{\circ} \mathrm{C}$ は $\mathrm{Al}-\mathrm{Si}$ スピネル 構造から遷移過程ムライト構造への相転移温度に 相当する。

Table 1 の酸密度はこの温度で急激に減少し, 酸強度も強くな る傾向はない。PA， AA の比生成速度は $1,300,1,500^{\circ} \mathrm{C}$ 焼 成後は漸減するが， $1,000^{\circ} \mathrm{C}$ 以下の試料に 比べると高い水準 を保持している。約 $980^{\circ} \mathrm{C}$ 以上で生成するクリストバライト $\mathrm{SiO}_{2}$ が $\mathrm{PO}$ 異性化反応に活性を示さないことは別途確認され ている。したがって遷移過程ムライトおよびムライト表面上の 活性点の性格は同一で，単に酸点あるいは塩基点の減少による ものと考觉られる。

Fig. 4 は PA および AA の比生成速度と $\mathrm{H}_{0} \leqq+4.8$ の酸 密度の関係を示している。焼成温度 $1,100^{\circ} \mathrm{C}$ 以上では $\mathrm{PA}$, AA の比生成速度は酸密度に比例している。一方, 上り低温域

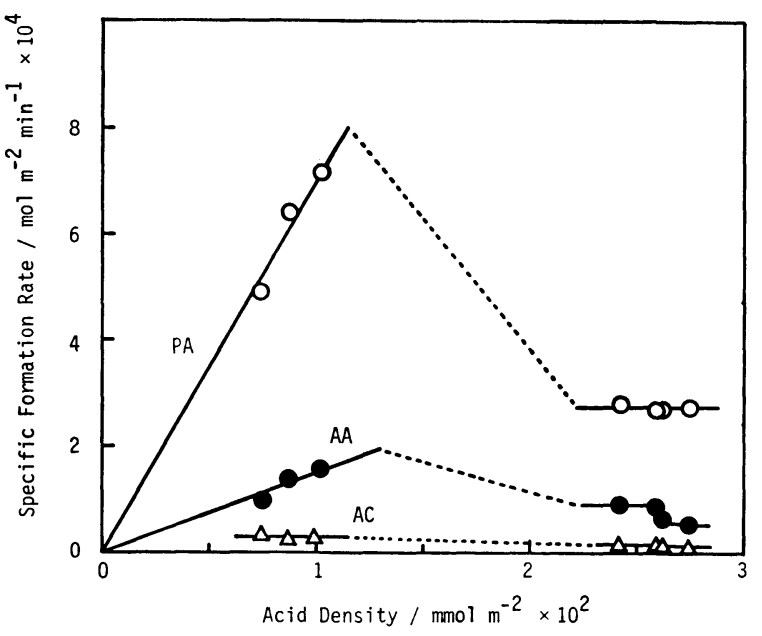

Fig. 4 Relationships between Specific Rates and Acid Densities (reaction temperature $300^{\circ} \mathrm{C}$ )

では AA は酸密度の増大につれやや減少し, PA は全く依存 性を示さず，乙かも両者とも酸密度の大きさに比べて比生成速 度は異常に小さい。これらの結果は $1,000^{\circ} \mathrm{C}$ 以下の焼成試料 上の酸点の一部は反応に関与していないことを示唆している。

ここで, 滴定法で酸量を求めたときの $n$-ブチルアミンが End on 型でL酸点上に吸着し, 吸着種間の相互作用はないも のとすると $n$-ブチルアミンの全吸着分子数は

$$
a[\mathrm{mmol} / \mathrm{g}]=\frac{a N \times 10^{-3}}{S}\left[\text { molecules } / \mathrm{m}^{2}\right]
$$

ここで $a$ は $n$-ブチルアミンの吸着モル数, $N, S$ はアボガ ドロ数, 比表面積である。

一方, 触媒表面上の酸点が均一に分散し, 六方最密充て几構 造をとると仮定すると，一辺 $l[\mathrm{~m}]$ からなる表面上に存在する 酸点の数は,

$$
\left(\frac{l}{\delta}+1\right)\left(\frac{l}{\sqrt{\frac{2}{3}} \cdot \delta}+1\right)=\sqrt{\frac{3}{2}} \cdot \frac{l^{2}}{\delta^{2}}
$$

単位表面積当たりでは

$$
\sqrt{\frac{3}{2}} \cdot \frac{1}{\delta^{2}}\left[\text { site } / \mathrm{m}^{2}\right]
$$

となる。ここで $\delta$ は酸点間距離で $\delta \ll l$ である。Eq. (5) と (7) を等值とおいて $\mathrm{H}_{0} \leqq+4.8$ の酸量から $\delta$ を推定した。その 結果は Table 1 の最右欄の数值となる。 $1,000^{\circ} \mathrm{C}$ 以下では $0.27 \sim 0.29 \mathrm{~nm}, 1,100^{\circ} \mathrm{C}$ 以上では $0.44 \sim 0.52 \mathrm{~nm}$ となり, 酸点間距離に明らかな差異のあることがわかる。Figs. 3,4で 見られる両焼成領域の比生成速度の大きな差異はこの酸点間距 離と反応分子サイズの対応性に起因していると考兄られる。酸 塩基の概念から酸点と塩基点は最近接位置に対を作って存在す ると考えられるので, 例えば焼成温度 $1,100^{\circ} \mathrm{G}$ 以上の場合に は酸点一塩基点の平均的距離は $0.22 \sim 0.26 \mathrm{~nm}$ と推定され る。一方 $\mathrm{PO}$ 分子の長径は約 $0.42 \mathrm{~nm}$ で, またメチル基炭素 とエポキシ環酸素との直線距離は約 $0.25 \mathrm{~nm}$ と見積られる。 したがって活性点間距離と PO 分子の骨格の長さとは非常に 良い対応性を有している。 


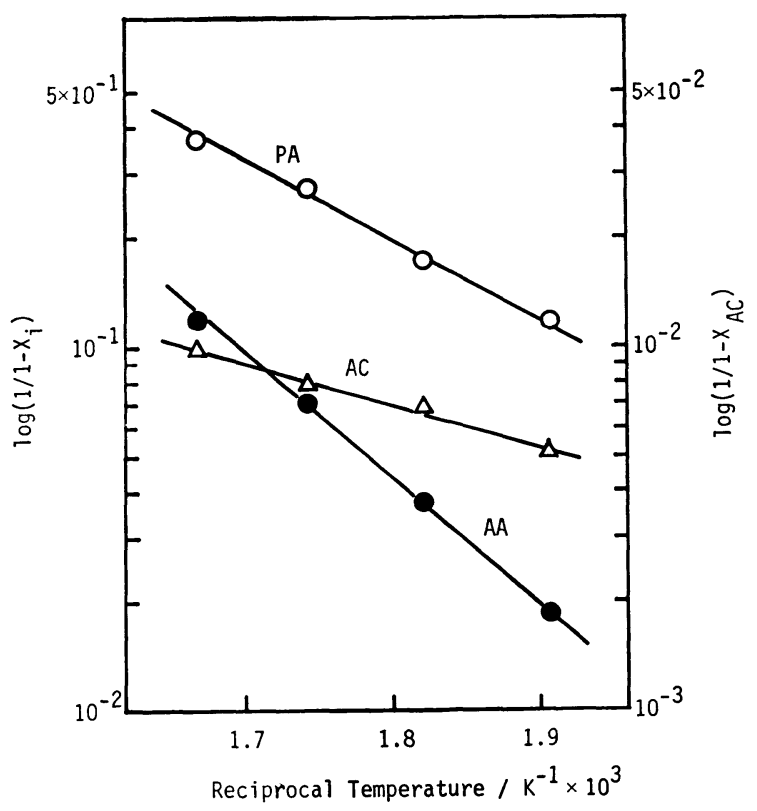

Fig. 5 Plots of $\log \left(1 / 1-x_{\mathbf{i}}\right)$ against Reciprocal Temperature on Kaolin Calcined at $1,000^{\circ} \mathrm{C}[x \mathrm{im}$ plies conversion and $i$ is $\mathrm{PA}, \mathrm{AA}$, or $\mathrm{AC}]$

Table 3 Apparent Activation Energy

\begin{tabular}{c|ccc}
\hline \multirow{2}{*}{ Galc. Temp. $\left({ }^{\circ} \mathrm{C}\right)$} & \multicolumn{3}{|c}{$\Delta E\left(\mathrm{~kJ} \cdot \mathrm{mol}^{-1}\right)$} \\
\cline { 2 - 4 } & $\mathrm{PA}$ & $\mathrm{AA}$ & $\mathrm{AG}$ \\
\hline 900 & 34 & 59 & - \\
1,000 & 39 & 62 & 19 \\
1,100 & 32 & 66 & 21 \\
1,300 & 40 & 61 & - \\
1,500 & 38 & 61 & - \\
\hline
\end{tabular}

すべての異性化生成物の生成速度は反応温度とともに一様に 増大した。PA，AA および AG の生成は PO の一次反応で あり，パルス反応における一次反応則15)も満足した。Fig. 5 は， $1,000^{\circ} \mathrm{C}$ 焼成試料上で得た反応結果のアーレニウスプロッ トである。得られた各異性化反応の見かけの活性化エネルギー を Table 3 亿示す。 $1,100^{\circ} \mathrm{C}$ 焼成試料の場合に PA の活性 化ェネルギーがやや小さく，AA ではやや高い傾向をもつが特 に有意差があるとは言えない。これらの結果は焼成温度の差異 によらず各異性化物への反応径路は同一であり，試料表面の酸 密度あるいはバルク構造の変化にも影響されないことを示唆し ている。なお，反応温度の変化は特に $\mathrm{AA}$ の生成をより促進
し, $\mathrm{AA}$ と $\mathrm{PA}$ の生成速度比 $n_{\mathrm{AA}} / n_{\mathrm{PA}}$ は $250,275,300,325$ ${ }^{\circ} \mathrm{C}$ の順に $0.18,0.25,0.32,0.40$ と著しく大きくなった。他 の焼成試料でも同様の結果を与えた。これは反応温度の高いほ ぞメチル基水素の酸素原子上への移動速度が増大することに起 因する。この水素移動は塩基点の関与を必要とする。同体塩 基物質の一つであるアルミナ高温焼成物上では $0.6 \sim 0.8$ の $n_{\text {AA }} / n_{\text {PA }}$ が得られており ${ }^{15)}$, Table 2 と比較するとかなり高 い。したがって，既述のように指示薬ブロモチモールブルーを 発色できず, $\mathrm{CO}_{2}$ 吸着の IR 吸収スペクトルを与え得ない程 度の塩基点が高温で焼成されたカオリン上に存在すると解釈さ れる。

3.6 ピリジン, ジクロロ酢酸による被毒効果

$1,000^{\circ} \mathrm{C}$ 焼成試料を $400^{\circ} \mathrm{C}$, 真空排気処理したのち, 室温で Py 16 Torr に 30 分さらした。これを反応管につめ, キャリ ヤー中で $300^{\circ} \mathrm{C}, 30$ 分脱離させて反応活性を測定した。この あと順次 $25^{\circ} \mathrm{C}$ 間隔で脱離温度をあげて同様の 測定をした

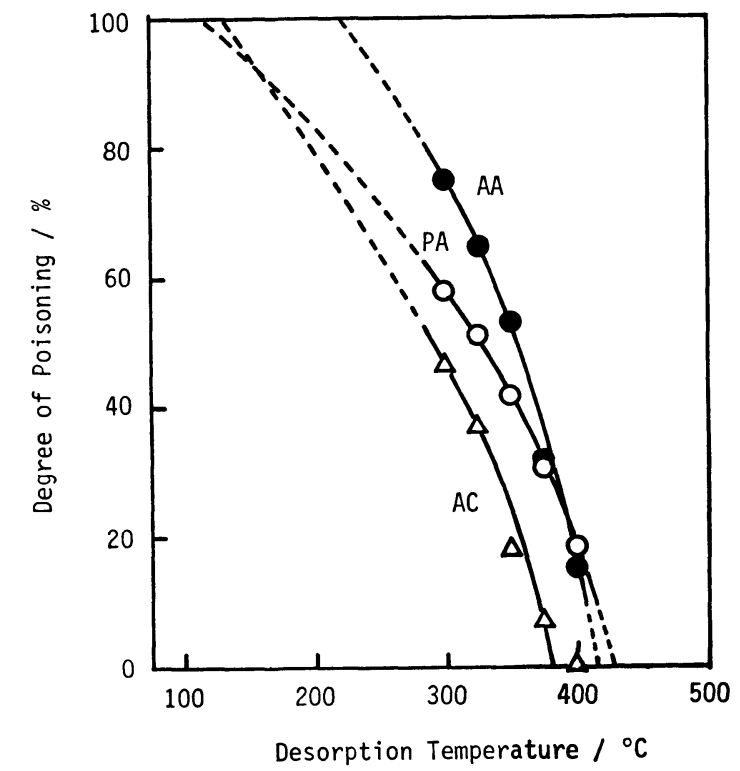

Fig. 6 Relation between Degree of Pyridine-Poisoning and Desorption Temperature of Pyridine Adsorbed on Kaolin Calcined at $1,000^{\circ} \mathrm{C}$ (reaction temperature $300^{\circ} \mathrm{C}$ )

[The degree of poisoning for each product is determined from $1-\left(r_{\mathrm{i}} / r_{0}\right)$, where $r_{1}$ and $r_{0}$ are the rates of formation obtained over poisoned kaolin and non-poisoned, respectively]

Table 4 Poisoning Effects of Dichloroacetic Acid (DCAA) on Kaolin Calcined at $1,000^{\circ} \mathrm{C}$ for $2 \mathrm{~h}$ in Air $* \mathrm{a}$ )

\begin{tabular}{|c|c|c|c|c|c|c|c|}
\hline \multirow{2}{*}{$\begin{array}{l}\text { Desorption } \\
\text { Temp. }\left({ }^{\circ} \mathbf{C}\right)\end{array}$} & \multicolumn{6}{|c|}{ Conversion $* \mathrm{c}) \quad(\mathrm{mol} \%)$} & \multirow{2}{*}{$\frac{n_{\mathrm{AA}}}{n_{\mathrm{PA}}}$} \\
\hline & PA & AA & $\mathrm{AC}$ & ACR & $\mathrm{PrOH}$ & PLM & \\
\hline $\begin{array}{c}\text { (non-poisoned) } \\
300 * \mathrm{~b}) \\
400 * \mathrm{~b})\end{array}$ & $\begin{array}{l}46.8 \\
24.0 \\
35.1\end{array}$ & $\begin{array}{r}14.8 \\
5.7 \\
12.5\end{array}$ & $\begin{array}{l}1.6 \\
1.1 \\
1.7\end{array}$ & $\begin{array}{l}0.6 \\
0.0 \\
0.5\end{array}$ & $\begin{array}{l}0.2 \\
0.0 \\
0.3\end{array}$ & $\begin{array}{l}0.7 \\
1.6 \\
1.5\end{array}$ & $\begin{array}{l}0.316 \\
0.238 \\
0.356\end{array}$ \\
\hline
\end{tabular}

*a) Kaolin sample was exposed to DGAA 10 Torr for $0.5 \mathrm{~h}$ at room temperature.

*b) DCAA-poisoned sample was kept at a given temperature for $0.5 \mathrm{~h}$ in a stream of helium carrier.

*c) Reaction temperature $300^{\circ} \mathrm{C}$. 
(Fig. 6)。すべての異性化反応が抑制を受け，AA への異性化 が最も抑制され，脱離温度依存性も大きい。被毒率 100 およ び $0 \%$ に外挿すると $\mathrm{PA}, \mathrm{AA}, \mathrm{AC}$ 生成に関与する酸点の強 度範囲の比較が 可能となる。この結果， PA，AA，ACはそ れぞれ 130〜 460，220～420，140～370 ${ }^{\circ} \mathrm{C}$ の温度範囲で表面上 に吸着している Py によって被毒されていることになる。AA の生成には三者の中では最も狭い領域の比較的強いL酸点が寄 与していることがわかる。

塩基点の被毒には $\mathrm{CO}_{2}$ と $\mathrm{DCAA}^{7}$ ) を用いた。前者は全く 抑制効果を示さなかった。室温で DCAA 5 Torr に 30 分さ らした試料 $\left(1,000^{\circ} \mathrm{C}\right.$ 焼成) 上で得た結果は Table 4 に示し た。AA の生成が著しい抑制を受けていることが明らかであ る。ここで問題となるのは PA， AC への異性化が抑制される ことである。DCAA が塩基点に吸着する場合には [ I ] と [II ] の吸着状態が考えられる。即ち，L酸点も被毒を受け， PA，AC の生成率が低下したと解釈される。吸着状態 [II] で は塩基点上の $\mathrm{H}^{+}$はブレンステッド酸として働き，PO のオリ ゴマー化に寄与していることが PLM 生成率の増大 (Table 2 の約 2 倍)によって説明される。

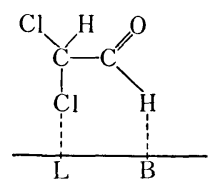

(I)

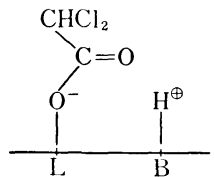

(II)
以上の結果，高温焼成カオリン上には L酸点と同時に塩基点 の存在が確認され，PA は L酸点上で， AA は L酸点と塩基点 の共役系で生成することも再確認された。なお，AC の生成は Brönsted および L 酸双方で起こると考兄られている ${ }^{16)}$ が，

Fig. 4 によれば塩基点の関与の可能性 7 も考えておく必要があ る。

\section{4. 結}

以上の結果から， $1,100^{\circ} \mathrm{C}$ 以上で焼成したカオリン（ムライ 卜構造をもつ) の表面上に酸性点（L酸）おょび塩基点として 働くサイトの存在することが明らかとなった。当然これらは強 度の弱いものであるが，酸量に関しては測定可能であった。塩 基点に関しては二酸化炭素吸着を起こし得ず，滴定法でも測定 不可能であったが，ジクロ口酢酸の室温吸着を可能とした。こ のような酸塩基性が安定なムライトセラミックスの表面にも存 在すると考えられる。本実験では, 加熱による結晶構造の変化 （固相反応の進行）途中に，これを外部から中断する方法をと
った。このことは表面組織の不均一性あるいは配位不飽和なサ イトの発生をらながしていると考えられる。

一般的に固体内の主な物質移動は空位を介するものであり, 空位濃度は高温ほど増大する。さらに格子点を飛び出して移動 する数も増大する。結晶中の空位あるいは格子欠陥すなわち配 位不飽和なサイトが活性点として働くことは良く知られてい る。カオリンの場合, クリストバライトの結晶外への払散移動 (Eqs. (2)〜 (4)) が高温下で促進され，ムライト構造の表面上 にL酸点, 塩基点が生成したものと考えられる。このような表 面の酸性, 塩基性はプロピオンアルデヒド, アリルアルュール 生成に最大限に寄与している。一方, $1,000^{\circ} \mathrm{C}$ 以下の表面の酸 量, 酸強度はすぐれているにもかかわらず十分には機能してい ない。考えられる一つの原因は酸点間距離もしくは酸点一塩基 点間距離とプロピレンオキシドの分子径, 骨格構造との整合性 であった。

\section{References}

1) Brindley, G. W., Nakahira, M., J. Am. Ceram. Soc., 42, 311, 314, 319 (1959).

2) Steadman, R., Touell, R. F., Nature (London), 180, 1066 (1957).

3) Hashimoto, K., Hamano, K., Seramikkusu no Kiso, p. 163, (1975), Kyoritsu Shuppan.

4) Garter, R. I., Delgass, W. N., Boudart, M., J. Catal., 18, 90 (1970).

5) Yonezawa, S., Shimizu, K., Yuki Gosei Kagaku, 26, 719 (1968).

6) Coudurier, M., Mathieu, M. N., Prettre, M., Imerik, B., Degeorges, M. E., Bull. Soc. Chim. Fr., 1968, 1821.

7) Imanaka, T., Okamoto, Y., Teranishi, Sh., Bull. Chem. Soc. Jpn., 45, 1353 (1972).

8) Okamoto, Y., Imanaka, T., Teranishi, Sh., Bull. Chem. Soc. Jpn., 46, 4 (1973).

9) France, G., Mathieu, M. B., Bull. Soc. Chim. Fr., 1970, 2891.

10) Price, C. C., Osgan, M., J. Am. Chem. Soc., 78, 4786 (1956).

11) Furukawa, J., Tsuruta, T., Saegusa, T., Sakata, Ry., Kakogawa, G., Kawasaki, A., Harada, M., Kogyo Kagaku Zasshi, 62, 1269 (1959).

12) Tajika, T., Ayame, A., unpublished.

13) Benesi, H. A., J. Am. Chem. Soc., 78, 5490 (1956).

14) Bassett, D. W., Habgood, H. W., J. Phys. Chem., 64, 769 (1960)

15) Abe, M., Ayame, A., unpublished.

16) Arata, K., Akutagawa, S., Tanabe, K., Bull. Chem. Soc. Jpn., 84, 1097 (1975). 


\title{
Summary
}

\section{Solid Acidity of Higher Temperature-Treated Kaolin and Isomerization of Propylene Oxide}

\author{
Masaki Abe and Akimi Ayame \\ Department of Industrial Chemistry, Muroran Institute of Technology, \\ 27 Mizumoto, Muroran, Hokkaido 050
}

\begin{abstract}
The acidity and basicity of kaolin surfaces calcined at 500 to $1,500^{\circ} \mathrm{C}$ in air were measured by titration with $n$-butylamine and benzoic acid using the Hammett reagent and by infrared analysis of the adsorbed pyridine and carbon dioxide. The activity for ring-opening-isomerization of propylene oxide was determined by the use of a pulse reaction technique.

With increasing calcination temperature, acidity decreased accompanying the solid phase transformation of kaolin in a manner similar to the surface area. Kaolin calcined at 500 to $1,000^{\circ} \mathrm{C}$, which had a metakaolin or $\mathrm{Al}-\mathrm{Si}$ spinel structure, showed a constant acid density of $\sim 0.026 \mathrm{mmol} \cdot \mathrm{m}^{-2}\left(\mathrm{H}_{0} \leqq+4.8\right)$. The acid density of the sample calcined at $1,100^{\circ} \mathrm{C}$ (transient mulite structure) was $\sim 0.010 \mathrm{mmol} \cdot \mathrm{m}^{-2}$, and at higher temperatures it decreased gradually (Table 1). The acid was Lewis-acidic in nature (Fig. 1).

In the isomerization of propylene oxide, the main products were propionaldehyde, allyl alcohol, and acetone. Acrolein and 1-propanol were observed as byproducts (Table 2). The specific rate of formation of the main products depended largely on the calcination temperature, that is, the specific rate of a sample calcined at $1,100^{\circ} \mathrm{C}$ was about two times that of the sample calcined at 500 to $1,000^{\circ} \mathrm{C}$ (Fig. 3). Concerning samples calcined at temperatures above $1,100^{\circ} \mathrm{C}$, the specific rates of propionaldehyde and allyl alcohol
\end{abstract}

were directly proportional to their acid densities, while below $1,000^{\circ} \mathrm{C}$ the specific rates were very small although their acidities were stronger and acid densities greater (Fig. 4).

The acid site-site distance estimated from the moles of $n$-butylamine adsorbed was $\sim 0.28 \mathrm{~nm}$ for the samples calcined at temperatures below $1,000^{\circ} \mathrm{C}$ and $0.44 \sim$ $0.52 \mathrm{~nm}$ above $1,100^{\circ} \mathrm{C}$ (Table 1). The latter values were very close to the size of propylene oxide molecule. The fact suggests that closeness of the active site-site distance to the molecular size of the reactant effectively promotes the catalytic reaction.

Pyridine-poisoning effects decreased in the order: allyl alcohol $>$ propionaldehyde $>$ acetone, and a comparison of their acid strengths responsible for their formation was made (Fig. 6). The presence of a base site could not be confirmed from the result of the infrared measurements using carbon dioxide nor from that of the titration method employing bromothymol blue (Table 1). Dichloroacetic acid was, however, adsorbed to retard all type of propylene oxide isomerization; and, its most pronounced poisoning effect was observed in the formation of allyl alcohol (Table 4).

From the results observed, it was evident that Lewis acid sites and weaker base sites persisted on the kaolin surface calcined at temperatures higher than $1,000^{\circ} \mathrm{C}$.

\section{Keywords}

Isomerization, Kaolin, Propylene oxide, Solid acid 